\title{
INTEGRATING THE MULTIMEDIA APPROACH IN MODERN EDUCATIONAL TECHNOLOGIES
}

\section{NiKOLAY S. GINCHEV, KRASIMIR M. KORDOV}

ABSTRACT: This article reflects the positive effect of integrating multimedia learning content in students' education. Multimedia lessons are developed and presented, that increase students' interest in the learning material and increase their knowledge and competencies.

KEYWORDS: e-learning, interactive methods, multimedia learning content

2020 Math. Subject Classification: 97P10, 97U50, 97U80

\section{ИНТЕГРИРАНЕ НА МУЛТИМЕДИЙНИЯ ПОДХОД В СЪВРЕМЕННИТЕ ОБРАЗОВАТЕЛНИ ТЕХНОЛОГИИ*}

\author{
НИКОЛАЙ С. ГИНЧЕВ, КРАСИМИР М. КОРДОВ
}

АБСТРАКТ: Настоящата статия отразява положителния ефект при използването на мултимедийно учебно съдържание в обучението на ученици. Разработени са и са представени мултимедийни уроци, които засилват интереса на учениците към учебното съдържание и задълбочават техните знания и компетенции.

\section{Въведение}

Целта на традиционното образование до 1990г. бе запаметяване и възпроизвеждане чрез авторитарни учебни подходи - натиск, манипулация, лозунги и културно насилие [1]. Новата образователна парадигма се основава на диалога,

\footnotetext{
*Сатията е частично финансирана по проект № РД-08$107 / 02.02 .2021$
} 
Ginchev N., Kordov K.

свободата и културното влияние. Ако традиционното образование изисква адаптация на хората към реалността, то критическият подход налага нейната творческа промяна според човешките нужди.

Днес, когато българското образование е поело по пътя на технологичните иновации [2], учителят е изправен пред сериозни предизвикателства към неговата компетентност, информираност, инициативност, съобразителност и адекватно поведение във всяка педагогическа ситуация. Съвременният учител успешно трябва да прилага в учебния процес компютьрните информационни технологии $[3,4]$. Особено е значението сред тях на мултимедийните технологии [5] като най-ефикасен инструмент за привличане и задържане на вниманието, представяне на знания и ускореното им възприемане и осмисляне от учениците.

Информационните технологии са добре познати на младежите от най-ранна възраст, които възприемат компютъра с любопитство и като партньор в различни виртуални игри. Компютьрно-подпомогнатото обучение формира познавателни умения, способства за развитие на абстрактното, логично и алгоритмично мислене на учениците. Интегралното вплитане на мултимедията в компютризирания дидактичен процес развиват психика и интелект, тъй като е свързана с ярки и завладяващи възприятия, които стимулират познавателните интереси на учениците. Под умелото ръководство на педагога-експерт, учениците леко и свободно боравят с маркера, избират подходящи цветове, при грешка изтриват с виртуалната гума. Поднесена на интерактивната дъска информация се запомня лесно и силно мотивира интерес към учене и развиване на образователните задачи [6]. По-гъвкавият възпитателнообразователен процес съвместява с традиционната учебна програма образователни игри и софтуерни продукти със занимателен, забавен и развлекателен характер [7,8]. Тези 
подходи подпомагат съществено Държавните образователни изисквания, доказано отговаряйки на учебните потребности.

\section{Компютьрна мултимедия}

Компютьрната мултимедия е комбинация от текст, графика, звук, анимация и видео, създадени в средата на компютърни програмни среди. Мултимедийните средства за информационно въздействие и за обучение съдържат значителен ресурс за активизиране на емоционално-познавателната сфера на потребителите. Това улеснява възприемането на нови знания и затвърждаване и упражнение на вече придобите умения. Използването на мултимедия дава възможност за въвеждане на интерактивност, което допълнително улеснява обучението на учениците.

В процеса на обучението, използването на мултимедия е изключително предимство, което улеснява учителите при представянето на учебния материал и им дава възможност да провеждат електронно и/или дистанционно обучение. Обобщените ползи от използването на компютърната мулдименя в процеса на обучение са:

- По-приятни уроци за ученици и учители чрез поразнообразни и динамични ресурси;

- По-голяма възможност да се интегрират ИКТ в уроците, докато се преподава пред класа;

- Лесно могат да споделят и използват материали повторно;

- Към различните стилове на учене се приспособяват различни ресурси, съответни на нуждите на учениците

- Не е задължително учениците да използват клавиатура, което дава възможност за обучение и на деца със специални образователни потребности;

- Към различните стилове на учене се приспособяват различни ресурси, съответни на нуждите на учениците. 


\section{Интерактивен мултимедиен урок за час по Компютьрна графика и дизайн - Adobe Photoshop}

Тема: Техники за рисуване на растерни изображения.

\section{Цели:}

- Затвърждаване, разширяване и прилагане на познанията на учениците за декоративна композиция;

- Формиране на декоративен усет, развиване на усет за ритъм и симетрия, на комбинативно и вариантно мислене и репродуктивно въображение;

- Запознаване с образци на български шевици, анализиране на стилизираните форми и варианти на композиционни решения;

- Стилизиране на растителни форми и създаване на декоративни проекти - шевици.

Оборудване: Компютьр, мултимедиен проектор, графичен таблет.

Очаквани резултати: Ученикът умее да създава и преработва:

- Растения и геометрични форми с определена декоративна цел, като осмисля ролята на стилизацията в този процес;

- Разграничава видовете декоративни композиции според начина на подреждане на декоративните елементи и мотиви;

- Изгражда определен вид отворена и затворена композиция, като подбира и ритмично редува украсителните елементи с цветови съчетания при изпълнение на декоративни проекти;

- Осмисля зависимостта между декоративния елемент и неговото предназначение, форма, големина и начина на обработката му. 
Задачи за постигане на поставените цели на урока:

- Конкретизиране на познанията за степените на стилизиране, на обобщаване на формите и цветовете в зависимост от вида на композицията;

- Обогатяване на образните представи при изграждане на декоративните мотиви и видовете декоративни композиции - линии, форми и цветове;

- Диференциране на представите за видовете декоративни мотиви и композиционни решения симетрични и асиметрични, отворени и затворени, чрез разглеждане на образци на шевици.

Задължителни задачи: Всеки ученик трябва:

- Да изпълни декоративна задача - създаване на шевица чрез стилизиране на растителни и геометрични елементи в определена последователност;

- Да използва познати декоративни елементи като ги редува ритмично.

Избираеми задачи: Всеки ученик самостоятелно трябва:

- Да определи обекта за стилизиране;

- Композиционното решение - брой на вид на декоративните елементи и мотиви както и начина им на комбиниране;

- Цветовото решение.

Методи на обучение: Основни методи са беседата и сравнителния анализ, онагледяването, словесните похвати - обяснение, указание, корекции и др.

Средства: Презентация, електронен ресурс, шаблон

Урокът е с продължителност 43 минути, като учителят разяснява основните понятия свързани с урока и под негово 
Ginchev N., Kordov K.

ръководство и напътствия учениците изпълняват поставените им задачи, като използват графичен таблет. На Фигура 1 е показан резултата при изпълнението на задачите.

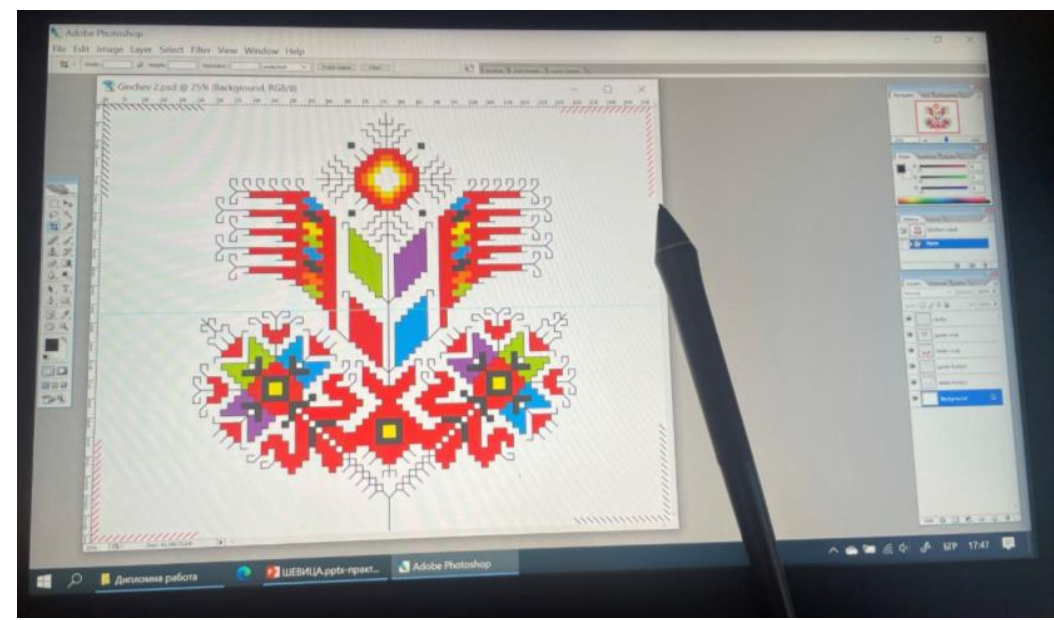

Фигура 1 - упражнение с графичен таблет

Интерактивен урок на тема извьршване и управление на видео проекти в Premiere Pro

Тема: Видеообработка.

Цели:

- Затвърждаване, разширяване и прилагане на познанията на учениците за видео обработка;

- Формиране на декоративен усет, развиване на усет за ритъм и симетрия, на комбинативно и вариантно мислене и репродуктивно въображение;

- Запознаване с образци на киното, анализиране на стилизираните форми и варианти на кадърни решения;

- Стилизиране на растителни форми и създаване на декоративни проекти - видео. 
Integrating the multimedia approach ... таблет.

Оборудване: Компютьр, мултимедиен проектор, графичен

\section{Очаквани резултати: Ученикьт умее да сьздава и преработва:}

- Комбиниране на части от видео и звукови клипове, които иска да превърне в поредица и да ги добави към панела с линията на времето.

- Поставя на специални ефекти за преходи между клиповете, добавя на видео ефекти и създава комбинирани визуални ефекти чрез разполагане на клипове на множество слоеве.

- Създава заглавия и графики и добавя към презентацията по същия начин, по който се добавя и към видеоклипа.

- Смесва звукови пътечки с цел улучване на правилни съчетания и използване на преходи и ефекти при звуковите клипове с цел подобряване на звука.

Задачи за постигане на поставените цели на урока:

- Разширено редактиране на звуци. Premiere Pro осигурява звукови ефекти и редактиране, с които не може да се мери нито един друг нелинеен редактор.

- Корекция на цветовете.

- Управление на проекти.

Задължителни задачи: Всеки ученик трябва:

- Да изпълни декоративна задача - създаване на клип чрез заснемането на кадри.

- Да използва познати декоративни елементи като ги поставя последователно и следва някаква ритмичност.

- Да използва софтуер в лицето на Premiere Pro позволяваща обработката на видео. 


\section{Избираеми задачи: Всеки ученик самостоятелно} трябва:

- Да определи на каква тема ще бъде видеото.

- Композиционното решение - брой кадри, декоративните елементи и мотиви както и начина им на комбиниране.

Методи на обучение: Основни методи са беседата и сравнителния анализ, онагледяването, словесните похвати - обяснение, указание, корекции и др.

Средства: Снимачна техника, софтуер (Premiere Pro), графичен таблет.

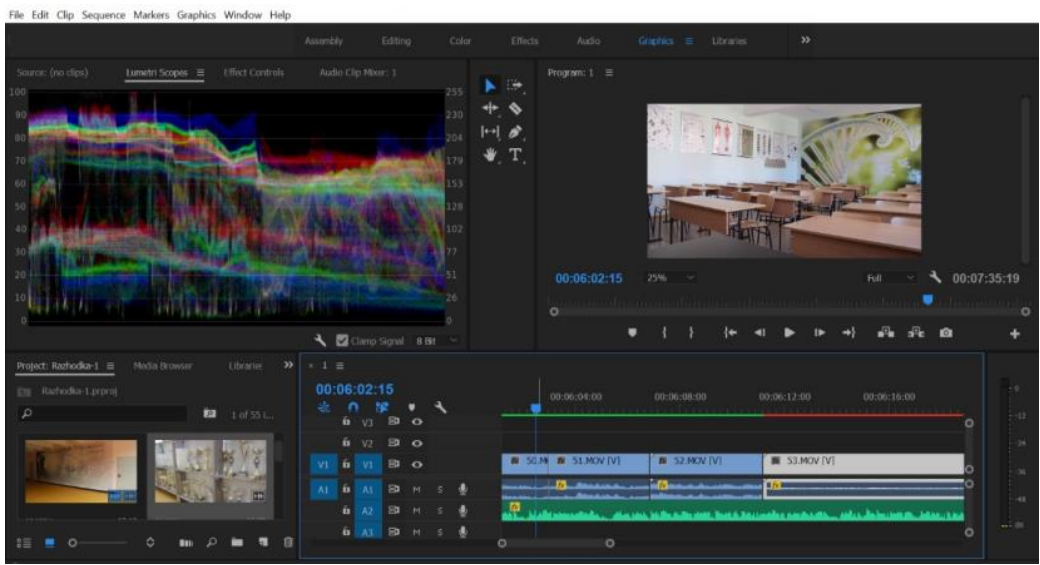

Фигура 2 - упражнение с графичен таблет

Урокът е с продължителност 43 минути, като учителят разяснява основните понятия свързани с урока и под негово ръководство и напътствия учениците извършват съответните дейности, свързани с изпълнение на поставените им задачи, като 
Integrating the multimedia approach ...

използват графичен таблет. На Фигура 2 е показан работният екран при изпълнението на задачите.

\section{Заключение}

Компютърната мултимедия заема ключова роля във всички аспекти на модерния живот. Навлизането на мултимедията в обучението вече е започнало, но има огромна необходимост от увеличаване на учебното съдържание, което да се преподава, чрез използване на мултимедия. Този подход води до засилване на интереса на учениците към учебния материал и спестява време на преподавателите, като им дава възможност за демонстрации и практически упражнения. Представените уроци в настоящата статия демонстрират адаптирано учебно съдържание, предназначено за усвояване от ученици, чрез използване на графични таблети.

\section{ЛИТЕРАТУРА:}

[1] Дончева, Ю. Рефлексивни характеристики на интерактивната образователна среда в началното училище, Сборник доклади от годишна университетска научна конференция, НВУ „Васил Левски“, брой 1, 2016, стр. 94-101, ISSN 2367-7481.

[2] Национална стратегия за въвеждане на ИКТ в българските училища, МОH, 2004.

[3] Павлова, Н., Харизанов, Кр. Технологии за описание на урок в обучението по математика, информатика и информационни технологии, Второ преработено и допълнено издание, УИ "Епископ Константин Преславски", Шумен, 2019, 264 с.

[4] Стефанов, С., Стефанова, А., Възможности за използването на ИКТ в технологичното обучение в прогимназиалния етап на българското училище, Сборник научни доклади от конференция с научнопрактическа насоченост и международно участие, стр. 184-187, София, 2013. 
Ginchev N., Kordov K.

[5] Тодорова, М., Монева, Хр. Мултимедийни технологии, УИ „Св. св. Кирил и Методий”, Велико Търново, 82 стр., 2006, ISBN-10: 9545245336.

[6] Harizanov, Kr., Petrova, R. VIRTUAL CLASSROOM INEDUCATION, Annual of Konstantin Preslavsky University of Shumenvol. XXI C, pp. 79 -90, 2020.

[7] Лазаров Л., Лазарова, С. Педагогически насоки за работа с интерактивна бяла дъска, Педагогически алманах, 2018, Том 26, Брой 1, стр. 11-23, 2018, ISSN: 1310-358X.

[8] Лазарова С. Обучение в дигитална среда. Университетско издателство „Св. св. Кирил и Методий“, Велико Търново, 424 стр., 2012, ISBN: 9789545248733.

\section{Николай Гинчев}

СУ „Панайот Волов“, гр. Шумен

e-mail: nikolai4000@abv.bg

Красимир Кордов

Шуменски университет „Епископ К. Преславски“

e-mail: krasimir.kordov@shu.bg 